\title{
Anti-Inflammatory Activity of Rhaphidophora pinnata (L.F) Schott Leaf Extract
}

\author{
Sumaiyah Sumaiyah ${ }^{1 *}$, Masfria Masfria ${ }^{2}$, Aminah Dalimunthe $^{3}$ \\ ${ }^{1}$ Department of Pharmacy Technology, Faculty of Pharmacy, Universitas Sumatera Utara, Medan 20155, Indonesia; ${ }^{2}$ Department \\ of Pharmacy Chemistry, Faculty of Pharmacy, Universitas Sumatera Utara, Medan 20155, Indonesia; ${ }^{3}$ Department of Pharmacy \\ Pharmacology, Faculty of Pharmacy, Universitas Sumatera Utara, Medan 20155, Indonesia
}

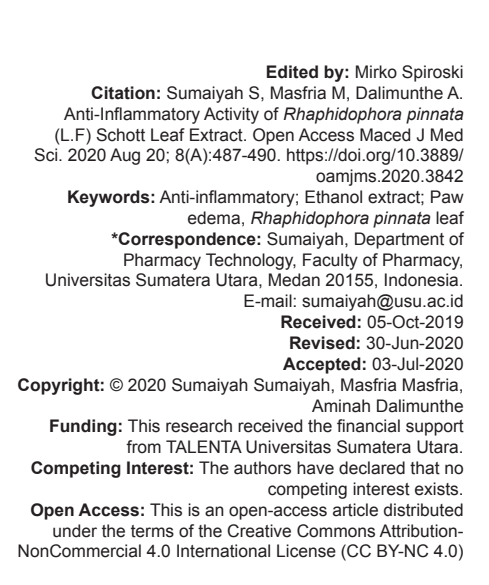

Abstract

BACKGROUND: Cancer growth is influenced by many factors and in general it is an interaction between gene factors and environmental factors, especially the microenvironment that exists around cancer. The inflammatory response plays a decisive role in various stages of cancer growth.

AIM: The aim of this study was to determine the anti-inflammatory activity of ethanol extract of Rhaphidophora pinnata leaves.

METHODS: R. pinnata leaf extract was obtained by percolation method using $96 \%$ ethanol as the solvent at room temperature. Anti-inflammatory activity was determined based on the paw edema method. Thirty male albino mice were treated orally with sodium carboxyl cellulose suspension (as negative control group), $R$. pinnata leaf extract $(35,70,140$, and $280 \mathrm{mg} / \mathrm{kgBW}$ ), and diclofenac (as positive control group), 60 min before $0.2 \mathrm{~mL} 1 \%$ carrageenan injection. The paw thickness was measured using plethysmometer before injecting the carrageenan and after 1, 2, $3,4,5$, and $6 \mathrm{~h}$.

RESULTS: The subplantar injection of carrageenan caused a time-dependent paw edema in the mice. Ora administration of $R$. pinnata leaf extract inhibited paw swelling at 1, 2, 3 4, 5, and $6 \mathrm{~h}$ after carrageenan injection. $R$. pinnata leaf extracts doses of $35,70,140$, and $280 \mathrm{mg} / \mathrm{kgBW}$ gave a percentage inhibition of $56.56 \%, 56.18 \%$, $62.77 \%$, and $49.30 \%$, respectively. The effective dose of $R$. pinnata leaf extract as an anti-inflammatory was 140 $\mathrm{mg} / \mathrm{kgBW}$

CONCLUSION: Ethanol extract of $R$. pinnata leaf has anti-inflammatory activity in male albino mice.

\section{Introduction}

Inflammation is a reaction toward infections or injuries, involving many kinds of mediators. Inflammation happens in two phases, namely, acute phase and chronic phase. Acute phase is a type of body immune when an injury occurs or when foreign objects enter the body, characterized by the presence of local vasodilation, platelet activity, or the increase of vascular permeability which causes liquid accumulation in the certain area. If the inflammation reaction fails and antigen settles persistently, then inflammation will grow into chronic. This is indicated by the leukocyte infiltration and the phagocytic cells in the area of inflammation [1], [2], [3].

Inflammation can increase the mutation rate and mutating cell proliferation caused by phagocytic activity. This indicated that inflammation and cancer cell have a reciprocal correlation; the damage on DNA inside cancer cell will worsen the inflammation process and promote the cancer [4].

One method to examine the anti-inflammation activity in a compound is paw edema method, which is inducted by carrageenan. Paw edema method is traditionally used for search and development of new nonsteroidal anti-inflammatory drugs (NSAIDs) for assessing inflammatory responses until $6 \mathrm{~h}$ after carrageenan induction [5]. Carrageenan are a complex group of polysaccharides, with three types: Lambda, kappa, and iota. This compound will cause an acute inflammation model and non-immune, indicated by the formation of edema, hyperalgesia, and erythema as a result of pro-inflammation mediator such as bradykinin, histamine, and reactive oxygen [4], [6]. Clinically, inflammation will be applied using NSAID, which is proven to be effective but will cause some side effects such as stomach irritation, osteoporosis, and disruption in cardiovascular system; hence, the other source of safer herbal plants are necessary as alternative therapy.

Rhaphidophora pinnata is a plant which is empirically used as an anti-cancer. The previous research showed that the leaf performs cytotoxicity activity with brine shrimp test method and MTT assays. $R$. pinnata also possess antioxidant activity with 1,1-diphenyl-2-pikrihidrazil, which is an active anticancer toward cell MCF-7 and is a antimutagenic [7], [8] . The previous study showed that $R$. pinnata had the 
potential to be an anti-cancer and hence possess the anti-inflammatory and analgetic activity. From the description above, the purpose of this research was to determine the inflammatory activity from the ethanol extracts of $R$. pinnata leaves.

\section{Materials and Methods}

Carrageenan were purchased from SigmaAldrich, ethanol p.a (Merck), methanol p.a (Merck), sodium carboxyl methyl cellulose (CMC), and aquadest were obtained from local supplier (Brataco Chemika, Medan, Indonesia); sodium diclofenac tablet was obtained from local pharmacy (Dexa Medica, Indonesia).

$R$. pinnata leaves were obtained from Medan city, North Sumatera on February 2019 and authenticated by the Research Centre for Biology, LIPI, Bogor, Indonesia. The leaves were cleaned by tab water, dried in oven at $40^{\circ} \mathrm{C}$ for 5 days, coarsely powdered, and kept in airtight container till use. The extraction process of $R$. pinnata leaves was done using percolation method with $96 \%$ ethanol as solvent at room temperature. The dried powdered leaves were macerated with $96 \%$ ethanol for $3 \mathrm{~h}$ and then the mixture was transferred into percolator chamber. The solvent was added with a flow rate of $1 \mathrm{~mL} / \mathrm{min}$ until the percolation was finished. The extract was concentrated in rotary evaporator and kept in desiccator.

The animal used in the experiment was a male albino mice of 2-3 months old and weighed around 20-30 g, obtained from Pharmacology Laboratory, Faculty of Pharmacy, Universitas Sumatera Utara. Before the mice were put under experiment, they were kept for approximately a week for adaptation to environment, for health and weight control, for uniformity of food, and also for the approval from the Ethical Committee of Biology Department FMIPA USU.

The anti-inflammatory activity from the ethanol extract of $R$. pinnata leaves was determined according to the swelling of the feet of the mice after carrageenan induction [1]. There were 30 mice, divided into six groups of treatment, with each group consists of five mice. Before examined, all of the animals were fasted for $18 \mathrm{~h}$, except for water. Food was not given at all during the observation. Group I, as the negative control group, was given $1 \%$ suspension of sodium carboxymethyl cellulose, Group II was given sodium diclofenac as positive control, while Groups III, IV, V, and VI were given the ethanol extract of $R$. pinnata leaves orally at various doses $35 \mathrm{mg} / \mathrm{kgBW}, 70 \mathrm{mg} / \mathrm{kgBW}, 140 \mathrm{mg} / \mathrm{kgBW}$, and $280 \mathrm{mg} / \mathrm{kgBW}$. Paw edema was induced by injecting $0.2 \mathrm{~mL}$ of $1 \%$ carrageenan into subplantar tissue of each mice paw. Mice paw was cleaned with ethanol $70 \%$ before injected. The paw thickness was measured using plethysmometer before injecting the carrageenan and after 1, 2, 3, 4, 5, and $6 \mathrm{~h}$ 5], [6]. The percentage of inflammation inhibition was determined based on the following formula:

$$
\% \text { inflammation inhibition }=\frac{a-b}{a} \times 100 \%
$$

Where, a=Edema volume of control group.

$\mathrm{b}=$ Edema volume of treatment group.

The data were expressed as Mean \pm SEM and analyzed using one-way ANOVA followed by post hoc Tukey to find the different variables [8]. Differences were considered as statistically significant at $p<0.05$ when compared with control. In this study, data were presented in tables and graphs.

\section{Results and Discussion}

Bioactive plant extract is resources for the development of anti-inflammatory agent with less side effect. Several studies have been conducted to prove the effect of flavonoids as anti-inflammatory. Flavonoids or polyphenol is good choice to use as anti-inflammation drugs because it could inhibit the production of free radical and lead to impede COX and LOX stimulation like Coptosapelta flavescens. Catechin and epigallocatechin gallate from green tea may inhibit COX2 expression induced by 12-O-tetradecanoylphorbol-13-acetate, tumor promoters in rat skin, and COX activity in macrophages induced by lipopolysaccharides [9], [10]. Quercetin-3-methoxy-40-glucosyl-7-glucoside from Maytenus heterophylla was effective as antiinflammatory against carrageenan-induced paw edema in rats [11]. The previous study showed that $R$. pinnata contain flavonoids, so it is possible to develop it as anti-inflammatory.

The anti-inflammatory activity of ethanol extract of $R$. pinnata leaves was done by the induction of $0.2 \mathrm{~mL}$ of $1 \%$ carrageenan at mice paw. The inflammation which was inducted carrageenan was described as a biphasic occurrence as various mediators were released to produce the inflammation responses. The first mediators were detected on early phase $(1 \mathrm{~h})$ including histamine, serotonin, and cyclooxygenase. On the other hand, final phase (more than $1 \mathrm{~h}$ ) was detected by the production of prostaglandin E2 (PGE2), mediated by bradykinin and leukotriene [9].

The anti-inflammatory activity of ethanol extract of $R$. pinnata leaves was showed by the gradually increased percentage of inflammation except on negative control group. The curve on negative control group continuously increased started from the $1^{\text {st }}$ to $6^{\text {th }} \mathrm{h}$ with significant statistics $(p<0.05)$ toward positive control on the $1^{\text {th- }} 6^{\text {th }} \mathrm{h}$. This happened on the 
group with the treatment of $1 \%$ sodium $\mathrm{CMC}$ due to the absence of medicine to ease the edema, causing the edema continued to grow. According to the statistic data, the negative control group indicated some significant differences toward the positive control group and treatment group ( $p<0.05)$. These data showed that the inducted carrageenan successfully formed an inflammation on the mice's feet. The lowest percentage of inflammation was seen from the extract activity with $140 \mathrm{mg} / \mathrm{kgBW}$ dose compared to the positive control group with sodium diclofenac and other treatment groups (Figure 1).

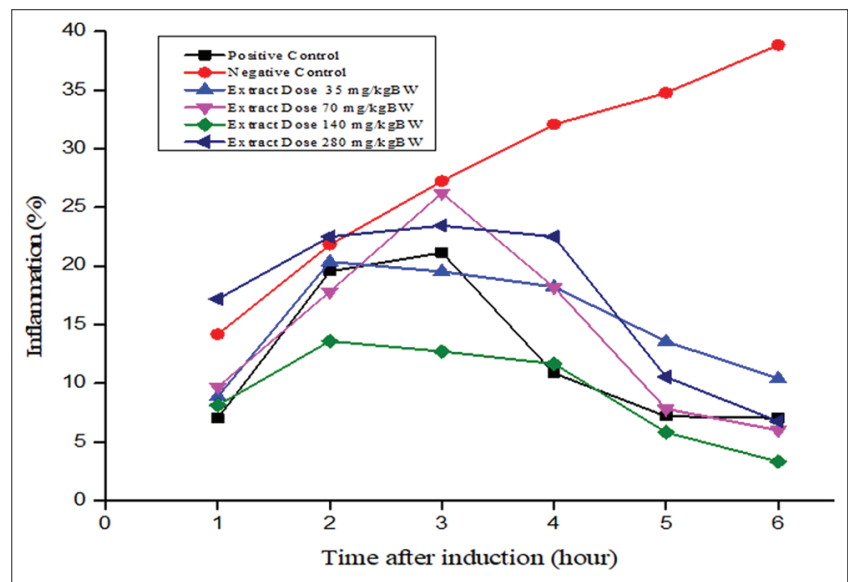

Figure 1: The percentage of inflammation by oral administration of diclofenac and ethanolic extract of Rhaphidophora pinnata leaves at $1,2,3,4,5$, and $6 h$ after the induction of edema $(n=5)$

The effects of inflammation inhibition were seen from the percentage in Figure 2. The negative control group did not show any inhibitions due to the absence of treatment. The bigger the inhibition percentage, the bigger the substance potential as an anti-inflammation. In contrast to the inflammation percentage, where smaller inflammation indicated the better potential for the substance as an anti-inflammatory. The $140 \mathrm{mg} /$ kgBW EERP activity showed the biggest inhibition percentage compared to positive control group and other treatment groups.

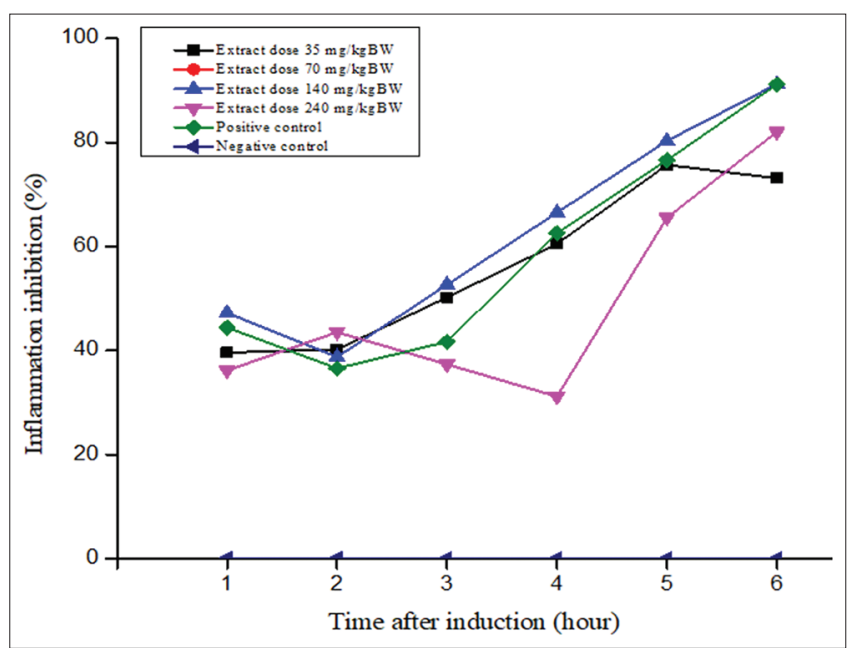

Figure 2: The percentage of inflammation inhibition by oral administration of diclofenac and ethanolic extract of Rhaphidophora pinnata leaves at $1,2,3,4,5$, and $6 \mathrm{~h}$ after the induction of edema $(n=5)$
The results of statistical analysis on inflammation percentage indicated that the dose treatment group did not possess any significant differences $(p>0.05$ ) compared to positive control group. It also did not possess any significant differences among dose treatment groups ( $p>0.05)$, which means that the dose treatment groups produce equal antiinflammatory activity to positive control group toward the other similar groups with dose treatment.

Table 1: The average inhibition percentage of ethanol extract from Rhaphidophora pinnata leaves extract

\begin{tabular}{ll}
\hline Dose $(\mathrm{mg} / \mathrm{kgBW})$ & Percentage of inhibition \\
\hline 35 & 56.56 \\
70 & 56.18 \\
140 & 62.77 \\
280 & 49.30 \\
\hline
\end{tabular}

The effective dose $50 \%\left(E_{50}\right)$ will cause therapeutic effects on $50 \%$ of population (median therapeutic dose). A medicine will produce effects if the concentration was on therapeutic range. $E D_{50}$ from the extract was determined to ensure the dose of ethanol extract of $R$. pinnata leaves reaching $50 \%$ of the inhibition. The value was summed using the linear equation between inhibition dose and percentage (Table 1 and Figure 3).

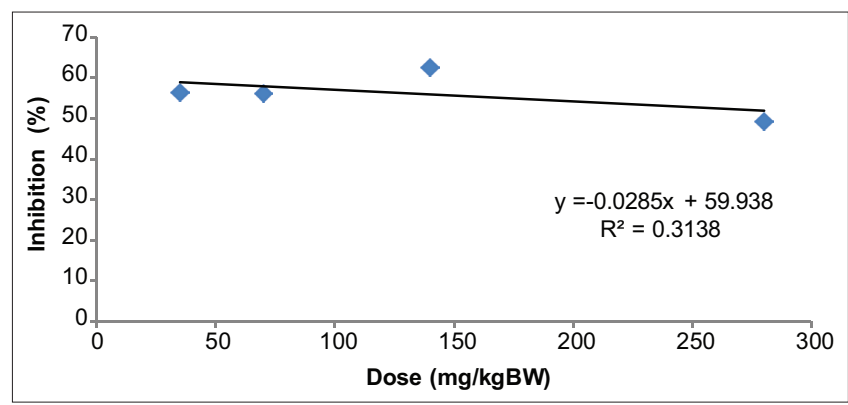

Figure 3: Linear regression of inflammation inhibition percentage

According to the linear regression that resulted from the equation, $y=-0.028 x+59.93$ with $R^{2}=0.3138$. From the equation, $\mathrm{ED}_{50}$ was summed from ethanol extract of $R$. pinnata leaves, where $Y$ is an effective dose percentage $(50 \%)$ and $x$ is the ethanol extract of $R$. pinnata leaves which inhibited the inflammation for $50 \%$. The calculation of $\mathrm{ED}_{50}$ ethanol extract according to the equation was as follows:

$$
\begin{aligned}
& y=-0.028 x+59.93 \\
& 50=-0.028 x+59.93 \\
& x=354.64 \mathrm{mg} / \mathrm{kgBW}
\end{aligned}
$$

Based on the calculation, the effective dose by $50 \%$ or $\mathrm{ED}_{50}$ from the ethanol extract of $R$. pinnata leaves was $354.64 \mathrm{mg} / \mathrm{kgBW}$. The effective dose by $50 \%$ from the leaf extract was deemed as less potent compared to the dose of sodium diclofenac by $25-50 \mathrm{mg}$, but the anti-inflammatory effect produced was $35 \mathrm{mg} / \mathrm{kgBW}$ or almost the same as sodium diclofenac. This shows that the smallest dose on ethanol extract of $R$. pinnata leaves was able to inhibit the formation of edema, the same as sodium diclofenac, proving that high dose was unnecessary in the inhibition of edema. 


\section{Conclusion}

It can be concluded that ethanol extract of $R$. pinnata leaves produces anti-inflammatory activity on male albino mice.

\section{References}

1. Kolawole OT, Akiibinu MO, Ayankunle AA, Awe EO. Evaluation of anti-inflammatory and antinociceptive potentials of Khaya senegalensis A. Juss (Meliaceae) stem bark aqueous extract. J Med Med Res. 2013;3(2):216-29. https://doi.org/10.9734/ bjmmr/2013/1931

2. Hafeez A, Jain U, Sajwan P, Srivastava S, Thakur A. Evaluation of carrageenan induced anti-inflammatory activity of ethanolic extract of bark of Ficus virens Linn. in Swiss albino mice. J Phytopharmacol 2013;2:39-43.

3. Azab A, Nassar A, Azab AN. Anti-inflammatory activity of natural products. Molecules. 2016;21(10):1321. https://doi.org/10.3390/ molecules21101321

4. Weitzman SA, Gordon LI. Inflammation and cancer: Role of phagocyte-generated oxidants in carcinogenesis. J Am Soc Hematol 1990;76(4):655-63. https://doi. org/10.1182/blood.v76.4.655.bloodjournal764655

\section{PMid:2200535}

5. Cong $\mathrm{HH}$, Khaziakhmetova VN, Zigashina LE. Rat paw oedema mondelling and NSAIDs: Timing of effects. Int J Saf Med 2015;27 Suppl 1:S76-7. https://doi.org/10.3233/jrs-150697 PMid:26639722

6. Sarkhel S. Evaluation of the anti-inflammatory activities of Quillaja saponaria Mol. saponin extract in mice. Toxicol Rep. 2015;3:1-3. $\quad$ https://doi.org/10.1016/j.toxrep.2015.11.006 PMid:28959520

7. Masfria H. The Activity of Rhaphidophora pinnata L.f. Schott leaf on MCF-7 cell line. Adv Biol Chem. 2013;3(4):397-402. https:// doi.org/10.4236/abc.2013.34042

8. Sumaiyah L, Masfria H, Dalimunthe A. Determination of total phenolic content, total flavonoid content, and antimutagenic activity of ethanol extract nanoparticles of Rhaphidophora pinnata (L.F) schott leaves. Rasayan J Chem 2018;11(2):50510. https://doi.org/10.31788/rjc.2018.1122068

9. Madhuri AS, Mohanvelu R, Ramabhimaida S. Evaluation of ant inflammatory activity of aqueous extract of Mangifera indica leaves in albino rats. Int J Basic Clin Pharmacol. 2016;5(3):6358. https://doi.org/10.18203/2319-2003.ijbcp20161451

10. Mondal A, Maity TK, Bishayee A. Analgesic and antiinflammatory activities of quercetin-3-methoxy-40-glucosyl7-glucoside isolated from Indian medicinal plant Melothria heterophylla. Medicines. 2019;6(59):1-11. https://doi. org/10.3390/medicines6020059

11. Kosala K, Widodo MA, Santoso S, Karyono S. In vitro and in vivo anti-inflammatory activities of Coptosapelta flavescens Korth Root's methanol extract. J Appl Pharm Sci. 2018;8(9):428. https://doi.org/10.7324/japs.2018.8907 